\title{
The Role of Eyewitness Testimony in Exonerations: An Archival Study
}

\author{
Avraham Levi* and Joseph Levi
}

\author{
The Hebrew University of Jerusalem, Faculty of Law, 33 Palyam, 97890 Jerusalem
}

\begin{abstract}
This paper deals with two issues related to exoneration cases: On the one hand, it examines the relative number of lineups used as the method of identification that resulted in mistaken identifications and false convictions. On the other, it compares eyewitness error as a cause of false convictions with other common causes. The original intent of the study was to concentrate only on the first topic. After defining some of the terms used in this paper, we will first outline our interest in the first issue, and then explain the widened focus of the paper.
\end{abstract}

Keywords: Exonerations, false convictions, eyewitness error, lineups, prosecution misconduct, false testimony.

\section{INTRODUCTION}

An exoneration occurs when a court reverses the previous conviction of a defendant. Eyewitness error was a cause of conviction whenever a witness mistakenly identified the defendant as the culprit. A lineup is a procedure in which witnesses are shown a number of people, the suspect and others known to be innocent ("foils"). If the witness picks the suspect, the police and courts tend to consider this an identification of the culprit. In North America photographs of the lineup members ("photo lineups") are usually used rather than the lineup members themselves ("live lineups").

Wells \& Seelau (1995) put forward the same reforms in identification procedure that were proposed later in a subsequent, prestigious "white paper" (Wells, et al., 1998) authorized by the American Psychological Association. The purpose of these two articles was to present the least possible reforms that could have maximal reduction in false identifications. Wells \& Seelau (1995) concentrate exclusively on the lineup in their proposals. They state that "following four simple rules of procedure ${ }^{1}$...can largely relieve the criminal justice system of its role in contributing to eyewitness identification problems" (p. 775).

This belief, and the exclusive focus on lineups, can only be justified if lineups so predominate as the cause of eyewitness error that we can ignore other sources. Is this so?

*Address correspondence to this author at The Hebrew University of Jerusalem, Faculty of Law, 33 Palyam, 97890 Jerusalem; Tel/Fax: 972-2-5815284; Email: avmlevi@netvision.net.il

\footnotetext{
${ }^{1}$ Rule 1: The person who conducts the lineup or photo-spread should not be aware of which member of the lineup is the suspect.

Rule 2: Eyewitnesses should be told explicitly that the person in question might not be in the lineup or photo-spread and therefore, should not feel that they must make an identification.

Rule 3: The suspect should not stand out in the lineup or photo-spread as being different from the distracters on the basis of the eyewitness's previous description of the culprit or other factors that would draw extra attention to the suspect.

Rule 4: At the time of the identification and prior to any feedback, a clear statement should be taken from the eyewitness regarding his or her confidence that the identified person is the actual culprit.
}

Psychologists are aware of other, more inferior, methods of identification. In the show-up, the witness is shown only one person, the suspect, and is asked if he or she is the culprit. The problem is that if witnesses choose, they will always seem to be correct. In a lineup, on the other hand, if the suspect is innocent such witnesses are more likely to pick one of the foils, because there is only one suspect and usually at least five foils. This proves to the police that the witness is incorrect. Despite some defense of show-ups as a legitimate identification method (Steblay et al., 2001; Wells, 2001), the consensus at the time among the experts (Kassin et al., 2001) was that show-ups cause more mistaken identifications than lineups, and the most recent accounts (Dysart \& Lindsay, 2007a; Dysart \& Lindsay, 2007b) weigh in against them.

Less attention has been paid to the mug-shot search. With a mug-shot search police show witnesses a large number of photos of people who have been arrested in the past and have been photographed, in the hope that witnesses will "identify" the culprit. The mug-shot search has been studied in terms of its potential negative effect on a subsequent lineup (Deffenbacher, Bornstein, \& Penrod, 2006; Memon, Gabbert, \& Hope, 2003), with little mention of the negative effects of presenting a mug-shot search by itself as evidence of an identification. Researchers are well aware of the weakness of the mug-shot search as evidence (Levi et al., 1995, Lindsay, et al., 1994) .In contrast with the lineup, in the mug-book search there are no true foils and the people whose photographs witnesses choose will be suspected.

Even less attention has been paid to spontaneous identifications and naming. Spontaneous Identifications occur when, without being requested by a police officer to make an identification, a witness "identifies" someone as the perpetrator. Naming occurs when the witness names the suspect, whom he is acquainted with. The experts are nearly silent on spontaneous identifications, perhaps because they are difficult to cause experimentally. A literature search retrieved only three references for "spontaneous identification". Two of these involved court cases. Theoretically, however, they are no more reliable than mug-shot searches. As with mug-shot searches, any hapless person that a witness "identifies" be- 
comes the suspect. There are no foils to protect suspects, as in lineups (Levi, 2005).

The possibility that witnesses can make mistakes in naming someone that they know seems to have been rarely considered. Young, Hay, and Ellis (1985) report on mistaken identifications of familiar people, but this was not in a forensic context. A noteworthy exception is England, where false identifications because of naming are unlikely, as lineups are conducted there even when witnesses claim to know the perpetrator. Indeed, Valentine, Pickering and Darling (2003) show in their Table 1 that $25 \%$ of witnesses who claimed to know the perpetrator failed to identify the suspect in British lineups.

All of these other methods are inferior to the lineup. We can safely assume that psychologists involved in eyewitness research are aware of these methods and their probative weakness. Whether they deserve our attention, however, depends of their prevalence in causing mistaken convictions. If they hardly happen, they can be safely ignored. The authors doubted that they were so rare, based on their personal experience with the Israeli criminal justice system (as police officer experts on eyewitness testimony, and for the senior author as an expert witness in eyewitness cases),

In Israel precedent of the Supreme Court has determined that a mug-shot search is as valid a method of identification as a photo lineup (Demanjuk v. State of Israel, 1988; Rokenshtien v. State of Israel, 1991); and in Shadid v. State of Israel (2003) the judgment stated that fairly conducted mugbook searches and photo lineups are of equal evidential weight. In Shitiyawi v. State of Israel (2005) there was no supporting evidence at all. A third of the eyewitness mistaken convictions in Israel studied (Levi, 2009) were due to mug-shot identifications.

If unreliable identification methods are common, and this is unknown to the only ones who know how unreliable they are (i.e. the researchers), there is nothing to prevent their continued use. Therefore this study focused on eyewitness cases and the identification method used to secure the conviction.

The Innocence Project (Conners et al., 1996), which has brought to date over 250 exonerations (The Innocence Project, 2010) by finding that the DNA of the convicts did not match that of the perpetrators, has had significant effects on the criminal justice system.

DNA, in particular in rape cases, has replaced eyewitness identification by the victim as the principal means of determining the guilt or innocence of suspects. The evidence suggesting that eyewitness identification was by far the major cause of the unjustified convictions (Scheck, Neufeld, P., Dwyer, 2001) has led to an unprecedented skepticism in the justice system towards eyewitnesses and openness to acceptance of innovative methods of identification (Wells, et al., 2000).

The importance of eyewitness error as a cause of mistaken convictions in exoneration cases has been embraced by psychologists researching eyewitness identification as a justification for their efforts. Numerous reports begin with mentioning this (for example, Bradfield \& McQuiston, 2004; Semmler, Brewer, \& Wells, 2004; Wells \& Bradfeld, 1998;
Wells \& Olson, 2003; Wells et al., 1998; Wells et al., 2000; Wogalter, Malpass, \& McQuiston, 2004). Some of the references claim a major preponderance of eyewitness error, though others are more circumspect.

With this in mind, we decided to examine some of the many exoneration cases that had eyewitness involvement in the original conviction. We expected this to be a rather small project, since we had been led to believe that we would quickly find many eyewitness cases.

For the need of a better method at the time, we started out with the Innocence Project exoneration cases reported on their Internet site (www.innocenceproject.org). We quickly discovered additional sites, and we examined their cases too. ${ }^{2}$ To our astonishment, we found ourselves gathering eyewitness cases at a far slower rate than we anticipated: many of the cases that we examined did not involve eyewitness error. There seemed to be only two reasonable explanations: either our sampling method was faulty, or eyewitness error in exoneration cases was far rarer than we had been led to believe.

Is eyewitness error the predominant cause of exonerated convictions, or is it only as important as other ones? While the perception of the predominance of mistaken identification may have been an important impetus for lineup reform, a less significant role would still justify improvement. However, if the role of the truthful eyewitness has been exaggerated, this error may reduce the perceived significance of other problems which therefore are not being sufficiently addressed by psychologists.

Wells et al. (2000) note that the representativeness of the Innocence Project is unclear, since most of cases were rape, and well they might. The most serious crimes played a major role in exoneration cases, since the effort required to exonerate someone is excessive for less serious ones (Gross et al., 2005). Therefore we would expect murder to play a major role. The role eyewitness error plays in these two serious crimes should differ. In rape cases the victim is usually the witness who makes the mistaken identification. In murder cases this is obviously rarely possible.

Lawyers, who have been the driving force behind exonerations, have found many causes of false convictions. In addition to eyewitness error, they mention false confessions, flawed forensics, false testimony, poor defense, judicial error

\footnotetext{
${ }^{2}$ Levi, A. M., \& Levi, J. (2008). The Innocence Project: Implications for eyewitness evidence. Unpublished manuscript. In this study we used the following databases:

Innocence Project (www.innocenceproject.org)

The Northwestern University site

(www.law.northwestern.edu/wrongfulconvictions/exonerations/illndex. html)

The Death penalty Information Center (www.deathpenaltyinfo.org), Dr. Edmund Higgin's List of Cases

(www.dredmundhiggins.com/listofcases.htm)

Frontline (www.pbs.org/wgbh/pages/frontline)

The Justice Project (www.thejusticeproject.org/problem/cases/josephamrine.html)

Truth in Justice (truthinjustice.org)

Centurion Ministries (www.centurionministries.org/)

Injustice Busters (http://news.injusticebusters.com/wordpress/) Justice Denied (http://justicedenied.org/jd_issue_27_spirko.pdf) Wikipedia (en.wikipedia.org/wiki/)

The major British site was Innocent (http://www.innocent.org.uk/)
} 
and police and prosecution misconduct. (The Innocence Project; Garrett, 2011). While psychologists may suffer from too much focus on eyewitness error, lawyers seem to suffer from too little focus. The conservative criminal justice system has difficulty introducing any reform. Some focus on no more than a few issues will be required to bring about change. The most predominant causes of false convictions are the best candidates for this effort.

On the other hand, perhaps our sampling method was at fault. We solved this problem by finding Sherrer's website (forejustice.org/db/innocents.html). He has created a website with a large list of entries, which is periodically updated. The database is organized by the name of the exonerated person. Most entries include the crime, country, dates of conviction and exoneration, the cause of the conviction, and references to other internet sites that describe the case. This study is based on a majority of the cases in the database during 2008 .

How representative is this database? Sherrer has written us that "We learn of exonerated persons from newspapers, books, magazines and court records." (Personal communication, December 13, 2011). A test of the degree to which Sherrer's database is comprehensive relative to other internet databases was conducted. The database was compared to 820 cases located in the initial study that we had conducted.. Sherrer's database included $89 \%$ of these cases. On the other hand, Sherrer's database included many more cases not found among the 820 cases. It seems that Sherrer missed some cases because he did not use the internet as a source for cases, but his site is by far the most comprehensive.

Sherrer includes in his database cases which were not formally exonerated. We have accepted his personal recommendation to ignore such cases, but this raises the question: What is a legitimate exoneration?

Gross et al. (2005) write "We have also excluded any case in which a dismissal was entered in the absence of strong evidence of factual innocence, or in which - despite such evidence - there was unexplained physical evidence of the defendant's guilt." The clear implication of this strategy was that an exoneration is only legitimate if we can be certain that the defendant was actually innocent. We have taken a different stance. In the absence of an ability to determine whether the defendant is actually guilty or innocent, the criterion for determining guilt is "beyond reasonable doubt". That is the burden placed on the prosecution to prove. Failure to meet that standard means failure to justifiably convict and then exoneration is warranted even if we cannot be sure that the defendant is innocent. . The British courts refer to convictions as being "unsafe" when they exonerate, which is a far cry from determining innocence.

Requiring proof of absolute innocence to exonerate would fundamentally bias the criminal justice system, as the burden of proof placed upon defendants to be exonerated would be much higher than that required to convict them in the first place. A conviction can be unjustified irrespective of the guilt or innocence of the defendant, and therefore causes of unjustified convictions should be based on all exonerations. Therefore we included exoneration cases where it may be possible that the defendant committed the crime, but given all the evidence and investigation activity, he should not have been convicted
The focus of our study became, thus, a test of two hypotheses: Our original one that much eyewitness error in exoneration cases would be based on identification methods that were inferior to the lineup, and our new one that we would discover other bases for conviction as predominant as eyewitness error.

\section{METHOD}

This study relied on searches in the internet. Seventeen letters were randomly picked ${ }^{3}$, and all the exonerated people on Sherrer's (forejustice.org/db/innocents.html) list whose surnames started with those letters were examined by the first author to determine the causes of conviction. Cases were chosen where the conviction occurred no earlier than the 20th century in countries with Western cultures. Any case that met those criteria and involved a clear exoneration by a court was included.

The purpose of the inspection was primarily to discover the causes of the wrongful convictions. Sherrer's database often gave one, but we required at least two concurring and non-identical sources to verify the cause, unless the one source was the exoneration court judgment. Sometimes a referral to a second source could be found in the database. The source was read to verify that it actually gave the same cause. Often it was necessary to independently search with Google, using as keywords the name of the person and the crime or the keyword "Exonerated". Up to four pages of results were searched for concurring causes.

In cases which involved multiple defendants only one was sampled. While true that in some multi-perpetrator cases different causes for error play a part for each of the defendants, we felt that the price of missing a few cases is less than that of giving excessive weight to a particular cause in a case by enumerating each suspect in the causes statistics.

Determining the precise identification method used when eyewitness error was a factor proved to be a more difficult task. Sources were often vague about the exact eyewitness identification procedure used, because of the use of summarized reporting and non-standard terminology and they were not always in agreement with each other. In order to maintain a high level of reliability, efforts were made to locate the most detailed reports and both authors read the sources to determine the identification method. Disagreements were resolved through discussion and further scrutiny. More sources were usually needed to determine the precise method of identification in these eyewitness cases and we did not always find two sources with sufficient description. In these cases the method was left undetermined for this study's purposes.

The reliability of the first author's categorization of the causes of conviction was tested. The second author sampled

\footnotetext{
${ }^{3}$ The sample size was determined by the need for an adequate number of eyewitness cases. The strategy of randomly sampling letters was chosen because it made the task far easier. Since using only part of the alphabet could possibly cause ethnic selectivity, i.e. no Hispanic names start with the letter W, which is not used in Spanish, we tested this using US Bureau of Census data for the 5,000 most common surnames, which account for the majority of the US population for the year 2000. Using part of the alphabet as we did, we selected $74.5 \%$ of the White, non-Hispanic population, $75.5 \%$ of the Hispanic population and $76.1 \%$ of the Black population.
} 
30 cases and categorized them independently. We found an $83 \%$ agreement.

\section{RESULTS AND DISCUSSION}

Table 1 gives the distribution of the cases by year of conviction and location, for those that had both year and location in the database. We note a spike in the years 1981 to 2000. In 1990 the Innocence project began. This created widespread interest in actively searching for false convictions, and bringing about exonerations,

We found two major crimes, 409 cases of murder (54\%), and 171 cases of rape $(22 \%)$. We aggregated other offenses that have been termed "violent crimes" (Bureau of Justice Statistics; Vaillancourt, 2010), to a "robbery \& other violent crimes" category (110 cases, 14\%). Other crimes accounted for $10 \%$.

Table 2 gives the distribution of causes of conviction for these categories. Other causes and crimes (that would have resulted in expected values in cells of less than 5 in a $\chi 2$ test) were aggregated in "other" categories. We were left with five major causes, prosecution (including police) misconduct ( $31 \%$ of the causes), false testimony $(24 \%)$, eyewitness error $(18 \%)$, false confession (12\%), and bad forensics $(8 \%)$. Other causes, which included bad defense and judicial error, are $7 \%$. False testimony is significantly less frequent than prosecution misconduct $(\chi 2=8.025$, df. $=1, p<0.001)$, and more frequent than eyewitness testimony $(\chi 2=10.034, \mathrm{df} .=$ $1, \mathrm{p}<0.001)$.
We recognize that the accepted method of presenting the statistics for causes of false conviction is the percentage of cases with the cause, i.e. "70\% of false convictions involved eyewitness error". However, we are interested in comparing the prevalence of a number of causes, when most cases have multiple causes. We therefore have presented our data in terms of the proportion of the cause among all causes. For statistical comparison the unit must be each cause reported. While our sample consists of 762 cases, Table 2 reports 1,124 causes.

Table 3 presents the same number of causes and displays the frequency of causes for each crime category. Prosecution misconduct and false testimony are the predominant causes for murder (38\% and $26 \%$ of the causes), while eyewitness error is the predominant one for rape $(48 \%)$. There is thus a significant interaction between type of crime and cause of conviction $(\chi 2=150.723$, df. $=18, p<0.001)$. The overall lead of misconduct is due to the predominance of murder (54\% of the cases).

A median split (of cases with a conviction date until 1986 or after) was carried out to test for changes over time. Table 4 gives the results. The interaction between time period and cause of mistaken conviction is significant $(\chi 2=28.797, \mathrm{df}$. $=4, \mathrm{p}<0.001)$. While the more predominant categories have remained very stable over time, false confessions have decreased (from $22 \%$ to $12 \%$ ), while forensic errors have more than doubled, from $7 \%$ to $17 \%$.

Table 1. The Distribution of the Cases by Location and Year of Conviction

\begin{tabular}{|c|c|c|c|c|c|}
\hline 12 & 66 & 17 & 3 & 2 & United Kingdom \\
\hline 2 & 33 & 9 & 10 & 5 & California \\
\hline 3 & 28 & 2 & 0 & 0 & West USA $^{1}$ \\
\hline 2 & 20 & 10 & 2 & 3 & New England ${ }^{2}$ \\
\hline 6 & 19 & 6 & 3 & 4 & Penn., Michigan \\
\hline 2 & 38 & 6 & 3 & 5 & Southeast USA ${ }^{3}$ \\
\hline 6 & 31 & 12 & 3 & 12 & Mid East USA ${ }^{4}$ \\
\hline 3 & 28 & 5 & 1 & 4 & Mid West USA ${ }^{5}$ \\
\hline 14 & 17 & 9 & 2 & 2 & Other $^{6}$ \\
\hline
\end{tabular}

'.- Arizona, Colorado, Idaho, Montana, Nevada, New Mexico, Oregon, Utah, Washington, Wyoming.

-- Includes New Jersey.

3.- District of Columbia, Delaware, Maryland, North Carolina, South Carolina, Virginia, West Virginia.

4.- Alabama, Arkansas, Georgia, Kentucky, Louisiana, Mississippi, Tennessee.

5.- Iowa, Kansas, Minnesota, Missouri, Nebraska, North Dakota, Oklahoma, Wisconsin.

..- Australasia, Europe, Israel, Military, Virgin Islands, Mexico. 
Table 2. The Causes of Wrongful Conviction of the Exonerated

\begin{tabular}{|c|c|c|c|c|c|}
\hline & Murder & Rape & Other violent crimes & Other crimes & Total \\
\hline $\begin{array}{l}\text { Police/prosecution } \\
\text { Misconduct }\end{array}$ & $244(22 \%)$ & $34(3 \%)$ & $40(4 \%)$ & $33(3 \%)$ & $351(31 \%)$ \\
\hline False testimony & $167(15 \%)$ & $41(4 \%)$ & $38(3 \%)$ & $25(2 \%)$ & $271(24 \%)$ \\
\hline False confession & $93(8 \%)$ & $14(1 \%)$ & $16(2 \%)$ & $7(1 \%)$ & $130(12 \%)$ \\
\hline Eyewitness error & $44(4 \%)$ & $108(10 \%)$ & $34(3 \%)$ & $16(1 \%)$ & $202(18 \%)$ \\
\hline Bad forensics & $57(5 \%)$ & $21(2 \%)$ & $9(1 \%)$ & $7(1 \%)$ & $94(8 \%)$ \\
\hline Other causes & $36(3 \%)$ & $9(1 \%)$ & $16(1 \%)$ & $15(1 \%)$ & $76(7 \%)$ \\
\hline Total causes & $641(57 \%)$ & $227(21 \%)$ & $153(13 \%)$ & $103(9 \%)$ & $1,124(100 \%)$ \\
\hline
\end{tabular}

Table 3. Frequency of Causes of Wrongful Conviction for Each Crime Category

\begin{tabular}{|c|c|c|c|c|c|}
\hline & Murder & Rape & Other violence crimes & Other crimes & Total \\
\hline $\begin{array}{l}\text { Police/prosecution } \\
\text { Misconduct }\end{array}$ & $244(38 \%)$ & $34(15 \%)$ & $40(26 \%)$ & $33(32 \%)$ & $351(31 \%)$ \\
\hline False testimony & $167(26 \%)$ & $41(18 \%)$ & $38(25 \%)$ & $25(24 \%)$ & $271(24 \%)$ \\
\hline False confession & $93(15 \%)$ & $14(6 \%)$ & $16(10 \%)$ & $7(7 \%)$ & $130(12 \%)$ \\
\hline Bad forensics & $57(9 \%)$ & $21(9 \%)$ & $9(6 \%)$ & $7(7 \%)$ & $94(8 \%)$ \\
\hline Other causes & $36(6 \%)$ & $9(4 \%)$ & $16(10 \%)$ & $15(15 \%)$ & $76(7 \%)$ \\
\hline Total causes & $641(101 \%)$ & $227(100 \%)$ & $153(99 \%)$ & $103(101 \%)$ & $1,124(100 \%)$ \\
\hline
\end{tabular}

Note: Percentages do not add up to $100 \%$, due to rounding

Table 4. The Major Causes of Wrongful Conviction of the Exonerated Until the End of 1986 vs. from 1987 (Median Split)

\begin{tabular}{|l|l|l|}
\hline & Until end of 1986 & From 1987 \\
\hline \hline $\begin{array}{l}\text { Police/prosecution } \\
\text { misconduct }\end{array}$ & $189(50 \%)$ & $159(41 \%)$ \\
\hline False testimony & $141(37 \%)$ & $130(34 \%)$ \\
\hline False confession & $82(22 \%)$ & $48(12 \%)$ \\
\hline Eyewitness error & $108(29 \%)$ & $94(24 \%)$ \\
\hline Bad forensics & $28(7 \%)$ & $66(17 \%)$ \\
\hline
\end{tabular}

Another useful way to examine the results is to compare the Innocent Project cases (from 1990), which base themselves on DNA testing, to other cases. The non-Innocence Project cases for this comparison were also from the United States, with an exoneration date from 1990 on. In our database there are 149 Innocence Project cases, 108 being rape (72\%).

There are 262 Non-Innocent Project cases, with only 29 of them rape $(11 \%)$. This difference is of course significant, $\chi^{2}=158.461(\mathrm{p}<0.001)$.
Table 5 gives the results for the causes separately for each category. We again note a very different pattern. Eyewitness error constitutes $53 \%$ of the error causes in the Innocence Project cases compared to $11 \%$ for the others. On the other hand, the Innocent Project has only 38\% misconduct, and $19 \%$ false testimony, compared to $45 \%$ and $32 \%$ of the non-Innocent Project cases. All of these comparisons are $\mathrm{p}<$ 0.001 by $\chi 2$.

Finally, we compared the causes of conviction between the USA, England and others. Table 6 presents the data. We calculated $\chi 2=38.509, \mathrm{df}=10, \mathrm{p}<0.001$. The major difference is the relatively high incidence of eyewitness error in the USA, $21 \%$ compared to $4 \%$ for England and $7 \%$ for the others.

The method we used presents a much lower figure for eyewitness error than the $70 \%$ that is frequently stated today. Why is this so? Our study found, as in previous research (Gross et al., 2005), that the eyewitness error exonerations occur primarily in rape cases, with DNA testing being the predominant exoneration evidence. Since DNA testing now is conducted as part of the police investigation, the role of eyewitness error in rape cases should be rapidly shrinking.

Recent previous analyses (Conners, 1996; Garrett 2011; Scheck, Neufeld, \& Dwyer, 2001; Wells,et al., 1998) were based on the Innocence Project. We have seen the 
Table 5. Crimes by Causes Separately for Innocence Project Cases and Others, from 1990

(a) Innocence Project Cases

\begin{tabular}{|c|c|c|c|c|c|}
\hline $\begin{array}{l}\text { Prosecution } \\
\text { misconduct }\end{array}$ & $18(38 \%)$ & $18(12 \%)$ & $1(10 \%)$ & $0(0 \%)$ & $37(18 \%)$ \\
\hline False test. & $9(19 \%)$ & $8(5 \%)$ & $1(10 \%)$ & $1(33 \%)$ & $19(9 \%)$ \\
\hline False conf. & $9(19 \%)$ & $8(5 \%)$ & $0(0 \%)$ & $0(0 \%)$ & $17(8 \%)$ \\
\hline Bad forensics & $3(6 \%)$ & $20(14 \%)$ & $1(10 \%)$ & $0(0 \%)$ & $24(12 \%)$ \\
\hline Total causes & $48(100 \%)$ & $146(100 \%)$ & $10(100 \%)$ & $3(100 \%)$ & $207(100 \%)$ \\
\hline
\end{tabular}

(b) Other Cases

\begin{tabular}{|c|c|c|c|c|c|}
\hline Misconduct & $107(45 \%)$ & $10(21 \%)$ & $27(44 \%)$ & $7(22 \%)$ & $151(40 \%)$ \\
\hline False conf. & $21(9 \%)$ & $1(2 \%)$ & $4(7 \%)$ & $2(6 \%)$ & $28(7 \%)$ \\
\hline EW error & $18(8 \%)$ & $6(13 \%)$ & $12(20 \%)$ & $4(13 \%)$ & $40(11 \%)$ \\
\hline Total causes & $238(101 \%)$ & $47(100 \%)$ & $61(100 \%)$ & $32(100 \%)$ & $378(100 \%)$ \\
\hline
\end{tabular}

Table 6. Crimes by Location

\begin{tabular}{|l|l|l|l|l|}
\hline & U.S.A & England & Other & Total \\
\hline \hline Misconduct & $261(29 \%)$ & $63(38 \%)$ & $20(28 \%)$ & 344 \\
\hline False test. & $211(24 \%)$ & $35(21 \%)$ & $20(28 \%)$ & 266 \\
\hline False conf. & $82(9 \%)$ & $30(18 \%)$ & $9(13 \%)$ & 121 \\
\hline EW error & $186(21 \%)$ & $6(4 \%)$ & $5(7 \%)$ & 186 \\
\hline Bad forensics & $90(10 \%)$ & $23(14 \%)$ & $8(17 \%)$ & 90 \\
\hline Other & $56(6 \%)$ & $9(5 \%)$ & $72(100 \%)$ & 56 \\
\hline Total causes & $886(100 \%)$ & $166(100 \%)$ & 1124 \\
\hline
\end{tabular}

predominance of rape cases in its data and that these also contribute to a relatively large number of eyewitness errors when compared to other crimes. It is quite possible that the high presence of DNA-containing exhibits in contested rape cases led to their review via the Innocence Project significantly more frequently than other crimes. DNA evidence is especially likely to be available in rape cases. This dovetails with the similar relatively large role of eyewitness error cases in the Innocent Project, since the victim's error as the witness has been a major cause of these mistaken convictions. In the cases that were not from the Innocence Project, only $10 \%$ of the causes were eyewitness error.

A second factor is that in many cases, eyewitness error often coexists with other causes for injustice. The frequency of eyewitness error among causes presents its relative contribution to injustice, which is lower than the frequency of eyewitness error among cases. In Table 5 we used 110 eyewitness error cases that were included in the Innocent Project, which account for $53 \%$ of the 207 total causes. These causes occurred in 149 cases. If we ignore the additional causes and divide the 110 eyewitness error cases by the total 149 cases, we get would get $74 \%$, a $40 \%$ increase over the $53 \%$.

That $74 \%$ of rape cases have eyewitness error as a cause is an accurate statement. However, it may lead to a neglect of other causes. If policy makers are unaware of the multiple causes of conviction and that only rape cases are being considered, it will seem to them that all other causes of convic- 
tions amount only to the remaining $16 \%$. We have seen that actually eyewitness error accounted for $18 \%$ of the causes of conviction in all the exoneration cases - less than police or prosecution misconduct and false testimony. As a percentage of cases rather than causes, Table 4 shows that the percentage increases to $27 \%$.

It is of course also true that other causes, such as misconduct and false testimony, also coexist with other causes. However, the focus has rarely been on these problems. Thus, no one has written, for example, that $70 \%$ of all cases have misconduct as a cause.

One might argue that it is much harder to exonerate someone who was convicted on the basis of eyewitness evidence, without counteracting evidence ${ }^{4}$. Perhaps. However, we noted the predominance of murder exonerations $(54 \%)$, where the tiny role of eyewitness errors $(7 \%)$ is likely due, not to the difficulty in countering eyewitness error, but rather to the scarcity of eyewitnesses in murder cases. This observation is strengthened by the "other violent crimes" category data, where eyewitness exonerations occur as often as misconduct and false testimony. If indeed, in the absence of DNA, eyewitness error is much harder to counter, we would expect far less eyewitness exonerations in this category.

Further, there is ample experimental evidence indicating that eyewitness testimony, while certainly a highly convincing form of evidence, is not always believed by laymen to be accurate (Lindsay, Wells, \& Rumpell, 1981; Wells, Lindsay, $\&$ Ferguson, 1979). Indeed, the Supreme Court of the US has recognized that eyewitnesses can err (Neils vs. Biggers, 1972), and even proposed certain standards by which to judge whether the witness was accurate or not ${ }^{5}$.

The relationship between DNA and eyewitness error exonerations has been amplified by the strategy of the Innocence Project to use DNA as the method to achieve exonerations, which led to a high proportion of rape cases, which frequently had the victim as the erring eyewitness. This most likely also explains the far higher incidence of eyewitness error in USA exonerations, where the Innocence Project operates.

However, the major issue is not belittling eyewitness reform. There must be many more less serious crimes that never reach exoneration that involved convictions based on eyewitnesses. Indeed, it is even possible that eyewitness testimony is predominant among less serious crimes as the cause for conviction.

We turn now to our original purpose of the study, to examine the methods used that caused eyewitness identification errors. First of all, of the $155(77 \%)$ cases for which we could determine the identification procedure employed, 34 $(22 \%)$ involved two identification attempts for the same witness, and with the suspect the only person appearing in these two attempts. These break down as follows: In 12 cases $(8 \%$ of all eyewitness error cases with the cause determined), the first attempt did not result in an identification. In 12 more cases $(8 \%)$, the first attempt resulted in a false identification.

\footnotetext{
${ }^{4}$ These criteria have not all withstood empirical test. The point is that the criminal justice system recognizes that eyewitnesses can err.

${ }^{5}$ Thanks to Tim Valentine and a reviewer for this idea.
}

In the remaining seven cases $(5 \%)$, the witness saw the suspect or his photo prior to the identification procedure.

We have already noted the research demonstrating the danger of presenting a lineup after a mug-shot "identification", as it is highly likely that the witness will choose the same person who was previously chosen. This creates the mistaken impression that the suspect was identified independently in a lineup rather than a mug-shot search. The same principle holds for conducting a live lineup after a photo lineup with the same suspect. This is true regardless of whether the witness chose the suspect in the first lineup or not (Hinz \& Pezdek, 2001). Obviously showing the witness a photo of the suspect prior to the lineup will increase the chance of him or her being "identified" (Godfrey \& Clark, 2010), whether he or she is guilty or not. Yet in a quarter of the eyewitness cases the witness saw the suspect or his photograph prior to the final identification procedure.

In five cases $(3 \%)$ the witness had constructed a composite of the culprit before the lineup. The witness will likely later 'identify" someone who looks like the composite, even when the composite is inaccurate (Jenkins \& Davies, 1985. but see Wells, Charman, \& Olson, 2005).

In all events, we consider the procedure which first caused the false identification to be the critical one. Of these, $82(53 \%)$ were lineups, while the other 74 cases $(47 \%)$ were fairly evenly divided between 16 spontaneous identifications $(10 \%), 19$ show-ups $(12 \%), 17$ cases of naming (11\%), and 22 mug-shot searches (14\%). Consistent with our hypothesis, rather than being a negligible factor, non lineups were used almost as much as lineups.

Additional factors were found which likely exacerbated the occurrence of eyewitness error. In 6 cases, hypnosis was used to assist the eyewitness in making an identification. It has been recommended that testimony of subjects to this procedure not be admissible as evidence (Anderton, 1986; Diamond, 1980; Orne, 1979; Perry, 1997). In 12 lineup cases, either bad foils or other suggestive methods were reported. Including multiple attempts, a total of 41 lineup cases (37\% of all critical lineups) were found to include faulty practices.

These numbers include only critical lineups - those that initially incriminated the suspect. Many cases included a supplementary lineup identification following a photo lineup or another procedure. However, these additional lineups are not fully legitimate identifications, as we have noted, as either the witnesses already identified the suspect, or they had failed to identify him or her in the previous attempt.

Finally, 29 (18\%) of the cases involved an identification procedure even though a significant discrepancy existed between the initial description of the culprit given by the witness and the actual appearance of the suspect. This finding suggests that the police should give greater weight to this indication of eyewitness error, even when the research evidence suggests a low association between witness accuracy in describing the culprit and their accuracy in identifying him or her (Pigott \& Brigham, 1985). Perhaps the discrepancy is due to the greater degree of mismatches that were found in the exoneration cases, compared to what accurate identifying witnesses faced in experiments. 


\section{GENERAL DISCUSSION}

We must emphasize that we should not confuse exoneration rates with wrongful conviction rates. Exoneration rates are influenced, in addition to conviction rates, by the priority and motivation attached to achieving them. The most extreme example is, of course, convicts given the death penalty and awaiting execution after having being convicted of murder. Thus, exoneration data cannot give us an accurate picture either of the relative rates of various crimes, or of the relative rates of causes of conviction. However, the consistent reference to exoneration rates still has significant merit. The importance attached to achieving exoneration is a significant index, perhaps far more important than conviction rates per se. Minor crimes rarely appear among exonerations precisely because the shorter length of incarceration means a lower priority.

Psychology and public policy can play important roles in reducing injustice. One avenue is to find ways to reduce judicial barriers to exonerations. It would be valuable to examine carefully England's experience with a special forum that reviews cases, and sends some of them back to the courts for renewed and more favorable consideration. It would seem even better to prevent wrongful convictions in the first place, and we will discuss these according to their causes.

Misconduct is the most predominant cause of mistaken convictions found in exoneration cases, yet it seems to be the least subjected to scientific scrutiny. To start with, while we would like to believe that only a small minority of police officers and prosecutors engage in such behavior, we do not know whether this is true or not. This is a critical issue. If the police and/or prosecution cheat in order to convict someone, no other reform will help. Exculpating evidence can be hidden, incriminating evidence can be invented. Yet preventing misconduct may be a very difficult mission. Therefore the degree to which this occurs is of outmost importance, as it may determine whether to invest the effort in reducing it or not.

Thus, the first step seems to be to sample randomly convictions and to conduct a rigorous investigation of each case to determine whether misconduct occurred. The lawyers who have been involved in uncovering such misconduct in the exoneration cases should be able to provide excellent advice on how to carry out such investigations.

If misconduct is more common than seems acceptable, there are other important research issues. First of all we might want to examine the degree that those who have engaged in misconduct have been sanctioned for their behavior. Reports of such sanctions are very rare, and we might assume that it is hard for the colleagues of the offenders, their fellow police officers and prosecutors, to seek such sanctions, or judges to apply them. If sanctions are rarely applied, we might want to explore ways to remedy this situation, and then examine the effects of increased sanctions on the rates of misconduct.

Other potentially promising avenues might be norms developed in the offending district attorney offices and the causes for these norms being developed, and individual difference factors. A non-malevolent confirmation bias from a priori guilt perception has been suggested (Tavris and Aronson 2007).
False testimony is often proffered by clearly unreliable individuals who have something to gain from strengthening the prosecution's case by lying, and by and large have indeed been offered incentives (prosecution misconduct). Psychological research aimed at exposing lying witnesses may be useful in removing this testimony. (This is particularly apt for those witnesses who are actually the perpetrators). Judges should be admonished to treat such testimony with extreme skepticism. It would be even better to raise the standards regarding individuals allowed to testify, in order to end this practice.

Garrett (2011) reports on a number of promising reforms. For example, Ontario's attorney general now limits the use of jailhouse informants to cases approved by a committee of senior prosecutors and only if "justified by a compelling public interest and founded on an objective assessment of reliability."(Province of Ontario, Ministry of the Attorney General, 2005). However, he notes that "the use of jailhouse informants has not received serious scrutiny". False testimony is strongly related to misconduct, since clearly the prosecution usually knows that the testimony is false. Efforts to reduce misconduct should therefore also reduce it.

The Canadian Criminal Justice system has paid special attention to eyewitness researchers (Levi 2009a). Canadian judges express a great deal of wariness regarding eyewitness identification in their judgments, compared to other judges who have minimal exposure to the eyewitness literature. As the result, Canadian judges falsely convicted far less often than other judges in a study of eyewitness cases (Levi, 2009).

We have noted that identification methods that are inferior to lineups have often been accepted as evidence in the exoneration cases. We have discovered that lineups account for only $52 \%$ of eyewitness error in the exoneration cases and out of those we found that in over a third, they were not fairly conducted. Along with dissemination of proper procedures, policy makers would also be well advised to keep in touch with further innovations being researched. These (for example, Levi \& Gotreib, 2012; Pryke et al., 2004) may further greatly reduce mistaken identifications.

We also discovered in the data two additional correlates of mistaken identifications. In $23 \%$ of the cases there was some form of multiple viewing of the suspect by the same witness. In $18 \%$ of the cases there was a mismatch between the initial description the witness gave of the culprit and the actual description of the suspect.

Our data suggests, then, that psychologists have a larger role to play than only pushing for lineup reform. We value that goal, but it is not sufficient in eliminating injustice, either with eyewitnesses or other players in the criminal justice system.

\section{CONFLICT OF INTEREST}

The author(s) confirm that this article content has no conflicts of interest.

\section{ACKNOWLEDGEMENT}

Declared none. 


\section{REFERENCES}

Anderton, C. H. (1986). The forensic use of hypnosis. In F. A. De Piano, \& H. C.Salzberg (Eds.), Clinical Applications of Hypnosis (pp. 197223). Norwood, N.J.: Ablex.

Bradfield, A., \& McQuiston, D. E. (2004). When does evidence of eyewitness confidence inflation affect judgments in a criminal court? Law and Human Behavior 28, 369-387.

Bureau of Justice Statistics. http://bjs.ojp.usdoj.gov/index.cfm?ty= tp\&tid=31 cases.justia.com/us-court-of-appeals/F2/800/77/270907/ $-43 \mathrm{k}$

Conners, E., Lundregan, T., Miller, N., \& McEwen, T. (1996). Convicted by juries, exonerated by science: Case studies in the use of DNA evidence to establish innocence after trial. Washington: U. S. Department of Justice.

Deffenbacher, K. A., Bornstein, B. H., \& Penrod, S. D. (2006). Mug-shot exposure effects: retroactive interference, mug-shot commitment, source confusion, and unconscious transference. Law and Human Behavior 30, 287-307.

Diamond, B. L. (1980). Inherent problems in the use of pre-trial hypnosis on a prospective witness. California Law Review 68, 313-349.

Dysart, J. E., \& Lindsay, R. C. L. (2007a). The effects of delay on eyewitness identification accuracy: Should we be concerned? In R. C. L. Lindsay, D. F. Ross, J. D. Read \& M. P. Toglia (Eds.) (2007), The Handbook of Eyewitness Psychology (Vol. II): Memory for People. NJ: Lawrence Erlbaum \& Associates.

Dysart, J. E., \& Lindsay, R. C. L. (2007b). Show-up identifications: suggestive technique or reliable method? In R. C. L. Lindsay, D. F. Ross, J. D. Read \& M. P. Toglia (Eds.) (2007), The Handbook of Eyewitness Psychology (Vol. II): Memory for People. NJ: Lawrence Erlbaum \& Associates.

Garrett, B. L. (2011). Convicting the Innocent. USA: Harvard University Press.

Godfrey, R., \& Clark, S. (2010). Repeated Eyewitness Identification Procedures: Memory, Decision Making, and Probative Value. Law and Human Behavior 34(3), 241-258.

Gross, S. M., Kristen, J., Matheson, D. J., Montgomery, N., \& Patel, S. (2005). Exonerations in the United States 1989 through 2003. Journal of Criminal Law \& Criminology 95, 523-560.

Hinz, T., \& Pezdek, K. (2001). The effect of exposure to multiple lineups on face identification accuracy. Law and Human Behavior 25, 185198

Jenkins, F., \& Davies, G. (1985). Contamination of facial memory through exposure to misleading composite pictures. Journal of Applied Psychology, 7, 164-176.

Kassin, S. M., Tubb, V. A., Hosch, H. M., \& Memon, A. (2001). On the "general acceptance" of eyewitness testimony research: A new survey of the experts. American Psychologist 56, 405-416.

Levi, A. M. (2005). Eyewitness identification for lawyers. Jerusalem: Academon Press. (In Hebrew).

Levi, A. M. (2009). A comparison of unjustified convictions in Canadian and Israeli eyewitness cases. Paper presented at 19th Conference of EAPL, Sorrento, Italy.

Levi, A. M., \& Gotreib, M. (2012). Much better than the sequential lineup: A 120-person lineup. Psychology, Crime \& Law 18, 631-640.

Levi, A. M., Jungman, N., Ginton, A., Aperman, A., \& Noble, G. (1995). Using similarity judgments to conduct a mug-shot search. Law and Human Behavior 19, 649-662.

Lindsay, R. C. L. (1999). Applying applied research: Selling the sequential lineup. Applied Cognitive Psychology 13, 219-226.

Lindsay, R. C. L., Nosworthy, G. J., Martin, R., \& Martynuck, C. (1994). Using Mug-shots to find suspects. Journal of Applied Psychology 79, $121-130$

Lindsay, R. C. L., Wells, G., \& Rumpel, C. M. (1981). Can people detect eyewitness identification accuracy within and across situations? Journal of Applied Psychology 66, 79-89.
Memon, A., Gabbert, F., \& Hope, L. (2003). The aging eyewitness. In J. Adler (Ed.)Forensic Psychology: Debates, Concepts, and Practice. Willan: Forensic Psychology Series.

Orne, M. T., Whitehouse, W. G., Dinges, D. F., \& Orne, E. C. (1988). Reconstructing memory through hypnosis: Forensic and clinical implications. In H. M.Pettinati (Ed.), Hypnosis and Memory (pp. 2163). New York: Guilford.

Perry, C. (1997). Admissibility and per se exclusion of hypnotically elicited recall in American courts of law. International Journal of Clinical and Experimental Hypnosis 45, 266-279.

Pigott, M. A., \& Brigham, J. C. (1985). Relationship between accuracy of prior description and facial recognition. Journal of Applied Psychology 70, 547-555.

Province of Ontario, Ministry of Attorney General (2005). In-Custody Informers, Crown Policy Manual. Pryke, S., Lindsay, R. C. L., Dysart, J. E., \& Dupuis, P. (2004). Multiple independent identification decisions: A method of calibrating eyewitness identifications. Journal of Applied Psychology 89, 73-84.

Semmler, C., Brewer, N., \& Wells, G. L. (2004). Effects of postidentification feedback on eyewitness identification confidence. Journal of Applied Psychology 89, 334-346.

Scheck, B., Neufeld, P., \& Dwyer, J. (2001). Actual innocence: When justice goes wrong and how to make it right. New York: Signet.

Sherrer, H. Wrongful convictions database. from: forejustice.org/db/innocents.html

Steblay, N., Dysart, J., Fulero, S., \& Lindsay, R. C.L. (2001). Eyewitness accuracy in police show-up and lineup presentations: A metaanalytic comparison. Law and Human Behavior 5, 523-540.

Tavris, C., \& Aronson, E. (2007). Mistakes were made but not by me. Harcourt, Inc. USA. Chapter 5. The Innocence Project Website, from: http://www.innocenceproject.org/[retrieved October 2010].

Vaillancourt, R. (2010). Gender differences in police-reported violent crime in Canada, 2008. Canadian Centre for Justice Statistics: Ottawa, Canada.

Valentine, T., Pickering. A., \& Darling, S. (2003). Characteristics of eyewitness identification that predict the outcome of real lineups. Applied Cognitive Psychology 17, 969-993.

Wells, G. L. (2001). Police lineups: Data, theory, and policy. Psychology, Public Policy, and Law 7, 791-801.

Wells, G. L., \& Bradfeld, A. L. (1998). "Good, you identified the suspect": Feedback to eyewitnesses distorts their reports of the witnessing experience. Journal of Applied Psychology 83, 360-376.

Wells, Gary L., Charman, Steve D., Olson, Elizabeth A. (2005). Building Face Composites Can Harm Lineup Identification Performance. Journal of Experimental Psychology: Applied 11, 147-156.

Wells, G. L., Linday, R. C. L,. \& Ferguson, T. (1979). Accuracy, confidence, and juror perceptions in eyewitness identification. Journal of Applied Psychology 64, 440-448.

Wells, G. L., Malpass, R. S., Lindsay, R. C. L., Fisher, R. P., Turtle, J. W., $\&$ Fulero, S. M. (2000). From the lab to the police station: A successful application of eyewitness research. American Psychologist $55,581-598$

Wells, G. L., \& Olson, E. A. (2003) Eyewitness Identification. Annual Review of Psychology 54,277-295.

Wells, G. L., \& Seelau, E. P. (1995). Eyewitness identification: Psychological research and legal policy on lineups. Psychology, Public Policy and Law 1, 765-791.

Wells, G. L., Small, M., Penrod, S., Malpass, R. S., Fulero, S. M., \& Brimacombe, C. A. E. (1998). Eyewitness identification procedures: Recommendations for lineups and Photo-spreads. Law and Human Behavior 22, 603-647.

Wogalter, M. S., Malpass, R. S., \& McQuiston, D. (2004). A national survey of US police on preparation and conduct of identification lineups. Psychology, Crime \& Law 10, 69-82.

Young, A. W., Hay, D. C., \& Ellis, A. W. (1985). The faces that launched a thousand slips: everyday difficulties and errors in recognizing people. British Journal of Psychology 76, 495-523. 